\title{
Stress and Relationship with Cognitive Disorders of Post-Stroke Patients
}

\author{
Agus Purnama*, Rina Afrina, Nurul Ainu Shifa \\ STIKES Indonesia Maju \\ purnama.aguz@gmail.com
}

\begin{abstract}
Conitive disorders will greatly interfere with activity in patients with a history of stroke. This will be exacerbated by chronic stress conditions, especially in patients who do not have a good coping mechanism. The design of this study is descriptive analytic with cross sectional approach with 75 post-stroke patients as outpatients at X Hospital. The instruments used in this study are standard instruments, DASS for stress questionnaires and MMSE for cognitive impairment. The results obtained are based on characteristic data, namely age over 46 years $(98.7 \%)$, female gender $(52 \%)$, high school graduate education $(40 \%)$, not working $(54.7 \%)$ and bivariate test results obtained $\mathrm{p}$ value 0.020 . the conclusion of this study is that there is a close relationship between stress and cognitive impairment in post-stroke patients. The expectation of this research is to be an important illustration that stress theory and cognitive function can be a reference in the process of solving problems that occur in poststroke patients
\end{abstract}

Keywords: Cognitive Function, Post Stroke, Stress, Elderly 


\section{STRADA Jurnal Ilmiah Kesehatan}

DOI: $10.30994 /$ sjik.v9i1.262

ISSN: 2252-3847 (print); 2614-350X (online)

Vol.9 No.1. May 2020. Page.1-5

\section{BACKGROUND}

Impaired cognitive function can cause disruption of daily activities where cognitive impairment is usually caused by a number of certain disease conditions (Neill, 2010). Poststroke cognitive impairment is included in Vascular Cognitive Impairment (VCI), which is a mild to severe cognitive impairment such as vascular dementia (Astuti, S.K. and Imam Rusdi, S.K., 2017). In previous studies of post-stroke cognitive impairment as much as $19.3 \%$ of post-stroke dementia and $11 \%$ of dementia in the control group (Ival et al., In Astuti, S.K. and Imam Rusdi, S.K., 2017). In other studies, $12.6 \%$ had cognitive impairment in patients and increased after 3-12 months without dementia, which was 39.5\% (Serrano, et al., 2007 in Astuti, S.K. and Imam Rusdi, S.K., 2017).

Cognitive disorders post stroke are quite common with prevalence between $20-80 \%$ in several countries, races and diagnostic criteria (Astuti, S.K. and Imam Rusdi, S.K., 2017). World Health Organization (WHO) report the prevalence of cognitive decline in 2013 in the world reached 38 million people, where the incidence of dementia in Europe reached 7 million people, in Asia reached 4.5 million people, in Malaysia reached 73 thousand people (Scoot, 2013 in Ridayani 2017).

Psychological functions such as stress can affect one's cognitive function so that the person experiences a decrease in memory, this can be explained that depression in patients with dementia or in patients with cognitive impairment will further aggravate the cognitive deficit of the patient. Depressive disorders must be considered when there are one or more conditions such as pervasive depressive mood, family history of depression or before the onset of dementia (Khairiah, 2015). The process of stress enters into the process of one's psychological functions, therefore stress must be avoided by patients with significant relapse rates, this has been explained in a study conducted by Abi Muhlisin with the title "the influence of stress factors on hypertension relapse in Bendosari Sukoharjo Health Center. "With the conclusion that there is a relationship with the level of recurrence between hypertension and stress (Muhlisin, 2013).

The purpose of this study is to look at the relationship between stress and cognitive function, especially those that occur in post-stroke patients in the hope that they can provide solutions and good coping mechanisms after this research is conducted.

\section{METHODS}

The research design in this study was an analytic descriptive plan where the approach used was cross sectional where the research was carried out at one time. This study aims to describe the relationship of stress and cognitive function in stroke patients. The population in this study were all post-stroke patients undergoing outpatient care at X Hospital, amounting to 75 patients. The size of the sample in this study were 75 respondents with a sampling technique that is total sampling. The instruments used in this study are standard questionnaires for stress, namely DASS (Depression Anxiety Stress Scales) and MMSE (Mini Mental State Examination) to measure cognitive function

\section{RESULTS}

Univariate data results obtained after conducting statistical tests illustrating the response characteristics studied are explained in table 1

\section{Characteristics Of Respondents By Age, Sex, Education And Occupation}

Data related to the description of respondents based on age, gender, education and occupation are listed in table 1 below. 
Table 1. Characteristics Of Respondents By Age, Sex, Education And Occupation

\begin{tabular}{|c|c|c|}
\hline Characteristics & Total (n) & Presentations (\%) \\
\hline \multicolumn{3}{|l|}{ Age } \\
\hline 26-45 Years & 0 & 1,3 \\
\hline$>46$ Years & 74 & 98,7 \\
\hline \multicolumn{3}{|l|}{ Gender } \\
\hline Male & 36 & 48 \\
\hline Female & 39 & 52 \\
\hline \multicolumn{3}{|l|}{ Educations } \\
\hline College & 18 & 24 \\
\hline Senior High School & 30 & 40 \\
\hline Junior High School & 12 & 16 \\
\hline Elementary school & 15 & 20 \\
\hline \multicolumn{3}{|l|}{ Occupation } \\
\hline Work & 34 & 45,3 \\
\hline Doesn't Work & 41 & 54,7 \\
\hline
\end{tabular}

Seen from table 1 above, it can be seen that the most age is $>46$ years (74\%), female gender with the number of 39 respondents (52\%), high school education totaling 30 respondents $(40 \%)$ and employment status is not working as many as 41 respondents $(54.7 \%)$.

\section{Relationship of Stress and Cognitive Function of Post-Stroke Patients}

Data on the relationship between stress and cognitive function is shown in table 2 below

Table 2. Relationship of Stress and Cognitive Function of Post-Stroke Patients

\begin{tabular}{lccccccc}
\cline { 2 - 6 } \multicolumn{1}{r}{ Stress } & \multicolumn{6}{c}{ Cognitive Function } & \\
\cline { 2 - 6 } & & Normal & \multicolumn{2}{c}{ Possible cognitive cognitive impairment } & P-Value \\
& $\mathrm{n}$ & $\%$ & $\mathrm{n}$ & $\%$ & $\mathrm{n}$ & $\%$ & \\
\hline Moderate & 3 & 4 & 8 & 10,6 & 3 & 4 & \\
Severe & 7 & 9,3 & 4 & 5,4 & 0 & 0 & \multirow{2}{*}{0,020} \\
Extremly & 22 & 29,4 & 27 & 36 & 1 & 1,3 & \\
Severe & 32 & 42,7 & 39 & 52 & 4 & 5.3 &
\end{tabular}

From table 2 above it is found that the most stress category is very bad with the number of 22 respondents (29.4\%) and cognitive function which is likely to occur as much as 27 respondents $(36 \%)$. From the bivariate statistical test results obtained $p$ value 0.020 means that there is a relationship between the two variables.

\section{DISCUSSION}

From the results of the above study it was found that the age of more than 46 years was the most common age in stroke patients with presetage $98.7 \%$ and only 1 respondent or $1.3 \%$ whose age was under 45 years. Pohjasvaara et al in his study said that cognitive decline and dementia often occur in ischemic stroke patients, and their frequency increases with increasing age (the incidence of stroke increases with age, the higher a person's age the 


\section{STRADA Jurnal Ilmiah Kesehatan}

DOI: $10.30994 /$ sjik.v9i1.262

ISSN: 2252-3847 (print); 2614-350X (online)

Vol.9 No.1. May 2020. Page.1-5

higher the likelihood of stroke (Yayasan Stroke Indonesia, 2012). In addition, the theory says that stroke will be affected by age by two times after the age of 55 years (Wahjoepramono, 2005) .In addition, research conducted by Yuliana states that increasing age triggers a decline in cognitive function (Yuliana, 2017). the most common stroke patients are 30 high school graduates, followed by the College of Respondents 18. This is also in line with what was stated by Supartini who stated that knowledge, behavior and attitudes can change a person (Supartini, 2004). health can also be it is an opportunity for someone to continually improve their knowledge and behavior for good health (Nursalam \& Efendi, 2008). In addition, research conducted by Purnama states that education is very important for patients with heart problems whose reasons may be the same as the cause of stroke (Purnama, 2020). In addition, results were obtained which stated that there were more women than men with a total of 39 respondents or $52 \%$. This can occur because after the age of menopause will decrease endurance, along with increasing age, also exacerbate the health problems of women of menopause. The main health problems during menopause are heart disease and stroke (Siagian, 2007). Even so this study is not in accordance with the theory which states that strokes occur in most men even though most deaths occur in women (Wahyu, 2009). Sari's research stated that a factor in the occurrence of stroke in women is menopause with age above 40 years (Sari, 2015).

From the results of bivariate analysis, p value of 0.020 obtained, which means that hypotheses can be stated that there is a relationship between stress and cognitive impairment of patients with post-stroke with a bad stress number of 27 in patients with cognitive impairment or $36 \%$. The results of the study in 2017 that people who have bad lifestyles such as experiencing stress, as well as with increasing age have double the risk compared with those who have good lifestyles, not stressed and age less than 45 years for a decline in cognitive function (Al Rasyid et al, 2017). The results of research conducted with respondents aged over 60 years who live in nursing homes, there are 28 elderly (57.1\%) who have severe dementia and 21 people (42.9\%) who have moderate dementia where based on the results of the study it was found that there was a relationship between stress and dementia in the elderly in nursing homes (Lestari, W \& Ngestiningsih, 2013). According to Yudawijaya's research, it was stated that there was a change in cognitive function in patients after ischemic stroke and a strong meaningful relationship was found (Yudawijaya, 2011). According to the author's assumption that from the results of the study that stress with cognitive function has a relationship with cognitive function that is equal to $2.6 \%$, this is because stress with specific cognitive functions is closely related, because in stressful situations an elderly person is very at risk of experiencing cognitive decline, especially an elderly person. It experiences a state of post-stroke so as to create a stressful condition tends to increase the risk of cognitive decline.

\section{CONCLUSION}

the conclusion of this study was that most post-stroke patients from the results of the study were female with age over 46 years, the last education was high school and status was no longer working. while the results of the bivariate analysis test results showed a significant relationship between stress and cognitive dysfunction in post-stroke patients. 


\section{STRADA Jurnal Ilmiah Kesehatan}

DOI: $10.30994 /$ sjik.v9i1.262

ISSN: 2252-3847 (print); 2614-350X (online)

Vol.9 No.1. May 2020. Page.1-5

\section{REFERENCES}

Al Rasyid, I., Syafrita, Y., \& Sastri, S. (2017). Hubungan faktor risiko dengan fungsi kognitif pada lanjut usia kecamatan Padang Panjang Timur kota Padang Panjang. Jurnal Kesehatan Andalas, 6(1), 49-54.

Astuti, S.K. and Imam Rusdi, S.K., 2017. Efektivitas Repetitive Transcranial Magnetic Stimulation Terhadap Perbaikan Fungsi Kognitif Pasien Gangguan Kognitif Vaskular Pasca Stroke Infark (Doctoral dissertation, Universitas Gadjah Mada).

Indonesia, Y. S. (2012). Tahun 2020, penderita stroke meningkat 2 kali. Yayasan Stroke Indonesia.

Khairiah, S., \& Margono, H. M. (2015). Aspek Neurobiologi Gejala Perilaku \& Psikologis Pada Demensia (Behavioral And Psychological Symptoms Of Dementia/BPSD).

Lestari, W., \& Ngestiningsih, D. (2013). Hubungan Antara Status Kognitif dengan Status Fungsional Lanjut Usia Panti Wredha di Semarang. Jurnal Kedokteran Diponegoro, 2(1), 137874.

Muhlisin, A., \& Laksono, R. A. (2013). Analisis pengaruh faktor stres terhadap kekambuhan penderita hipertensi di puskesmas Bendosari Sukoharjo.

Neill, J. C., Barnes, S., Cook, S., Grayson, B., Idris, N. F., McLean, S. L., ... \& Harte, M. K. (2010). Animal models of cognitive dysfunction and negative symptoms of schizophrenia: focus on NMDA receptor antagonism. Pharmacology \& therapeutics, 128(3), 419-432.

Nursalam, N., \& Efendi, F. (2008). Pendidikan Dalam Keperawatan Education in Nursing.

Purnama, A. (2020). Edukasi Dapat Meningkatkan Kualitas Hidup Pasien Yang Terdiagnosa Penyakit Jantung Koroner. Jurnal Kesehatan Indonesia, 10(2), 66-71.

Ridayani, 2017. Pengaruh Promosi Kesehatan, Lingkungan Sosial, Peran Tenaga Kesehatan, Dan Fungsi Keluarga Terhadap Fungsi Kognitif Pada Lanjut Usia Di Puskesmas Air Itam Kota Pangkal Pinang (Tesis).

Sari, I. P. (2015). Faktor-faktor yang berhubungan dengan terjadinya stroke berulang pada penderita pasca stroke (Doctoral dissertation, Universitas Muhammadiyah Surakarta).

Siagian, A. (2007). Saatnya Memperhatikan Kesehatan Wanita Usia Menopause.

Supartini, Y. (2004). Buku Ajar Konsep Keperawatan. Yogyakarta: Graha Ilmu.

Wahjoepramono, E. J. (2005). Stroke tata laksana fase akut. Jakarta: Universitas Pelita Harapan.

Wahyu, G. G. (2009). Stroke: Hanya Menyerang Orang Tua?. Bentang-B First.

Yudawijaya, A., Kustiowati, E., \& Pemayun, T. G. D. (2011). Homosistein plasma dan perubahan skor fungsi kognitif pada pasien pasca stroke iskemik. Media Medika Indonesiana, 45(1), 8-15.

Yuliana, W. (2017). Pengaruh Stimulasi Otak Terhadap Tingkat Kognitif Lansia Di Panti Werdha Bhakti Luhur. Jurnal Penelitian Kesehatan, 5(1), 1-5.

Zhu, L., Fratiglioni, L., Guo, Z., Aguero-Torres, H., Winblad, B., \& Viitanen, M. (1998). Association of stroke with dementia, cognitive impairment, and functional disability in the very old: a population-based study. Stroke, 29(10), 2094-2099. 